\title{
Communal Conflict in Indonesia: Contagious or Latent Issues?
}

\section{Sujarwoto}

\begin{abstract}
This paper examines socio, economic, and political factors of communal conflict in Indonesia and investigates how communal conflict is spatially correlated across districts. Data comes from the 2008 Village Potential Census (Podes) and official statistics which consist of communal conflict information across all Indonesia's districts $(\mathrm{N}$ districts $=465)$. Results from spatial dependent model show that communal conflict to be spatially dependent through latent factors, meaning that communal conflict clusters because of clustering of latent factors within district. Rather than religious and ethnic heterogeneity, communal conflict is positively associated with poverty, economic inequality, elite capture, and weak capacity of districts to manage fiscal resources.
\end{abstract}

\section{Keywords:}

communal conflict; spatial dependent; contagious; latent issue.

\begin{abstract}
Penelitian ini mengkaji faktor sosial, ekonomi dan politik sengketa komunal yang terjadi di Indonesia dan menguji bagaimana sengketa komunal secara spasial terhubung antarkabupaten atau kota di seluruh Indonesia. Data bersumber dari Sensus Potensi Desa (Podes) tahun 2008 dan laporan statistik pemerintah yang berisi informasi mengenai sengketa komunal di seluruh kabupaten/kota di Indonesia (N kabupaten/ kota=465). Penelitian ini menemukan bahwa sengketa komunal di Indonesia terjadi akibat adanya faktorfaktor laten di dalam kabupaten/kota. Dibandingkan dengan keragaman agama dan etnis, sengketa komunal memiliki hubungan kuat dengan kemiskinan, ketimpangan ekonomi, elite capture dan lemahnya kapasitas kabupaten/kota dalam mengelola sumber-sumber fiskal daerah.
\end{abstract}

\section{Kata Kunci:}

sengketa komunal, spatial dependent, contagious, isu laten

\section{Introduction}

Efforts to maintain collective security are at the heart of human history: from the earliest times, the recognition that human safety depends on collaboration has been a motivating factor for the formation of village communities, cities and nation-states. The $21^{\text {st }}$ century was dominated by interstate

\footnotetext{
- Lecturer at Brawijaya University.

Email: sujarwoto@ub.ac.id
}

communal conflicts and wars which threats human security and well-being across Africa, Middle East and Asia (UNDP, 2011). World Development Reports 2011 titled "Conflict, Security and Development" reports that deaths from communal conflicts and wars, while still exacting an unacceptable toll, are one-quarter of what they were in the 1980's. Violence and conflict have not been banished: one in four 
people on the planet, more than 1.5 billion, live in fragile and conflict-affected states or in countries with very high levels of criminal violence (UNDP, 2011). Yet, insecurity not only remains, it has become a primary social, political and economic development challenge in conflict-affected countries across Africa, Middle East and Asia. While much of the world has made rapid progress in reducing poverty in the past 60 years, areas characterized by repeated cycles of political and criminal violence are being left far behind, their economic growth compromised and their human development indicators stagnant (World Bank, 2011).

The history of communal conflicts in developing countries' context has put Indonesia in the list particularly after the 1998 political and economic crisis. During that period, the incidence of communal conflicts was not only substantially increase in number but also spread across districts of the country archipelagos. The government official statistics reports the incidence of communal conflict increases from 12 percent between 1990 and 1995 to 67 percent between 1997 and 2014 with a large percentage occurred between 1997 and 2002 (BPS, 2015). In 1997, the communal conflict between indigenous Dayaks and some indigenous Malays against the immigrant Madurese group in West Kalimantan caused around 4,500 people death and 670,000 displaced (BPS, 2011). In 1999, there was a conflict going in Poso, Sulawesi. The worst episode was this past spring when there were 300 people killed in the conflict between Christian-Muslim (BPS, 2010). Further, the conflict in the Moluccas between 1999-2002 where about 4,000 people have been killed in Christian-Muslim fighting, and about 500,000 displaces were the worst of the conflicts that Indonesia is facing but even there it is almost a misnomer to see it as arising from some long-seated religious dispute (BPS, 2011). Moreover, there were also periodic eruptions of communal conflict in Lombok, Eastern Bali, in Kupang in West Timor, in in West and East Java.
Not only because ethnicity and religious issues, but also there are a lot of historical, political and economic factors that are lying at the root of these communal conflicts (Klinken, 2007).

Studies on communal conflicts in Indonesia after the 1998 economic crisis have been linked to the role of political crisis and decentralisation reform in the early 1999 in producing communal conflicts (see for example, Murshed et al., 2009; Welsh, 2008; Klinken, 2007). All these studies documented that decentralisation reforms were associated with communal conflicts in some places. For example, Klinken (2007) documented democracy transition in Indonesia was far less peaceful than is often though. He reported that democracy transition in the country was followed by widespread communal conflicts which threatened more than 10,000 lives of people across archipelago. However, Murshed et al. (2009) found that routine social violence in Java is negatively associated with the impact of fiscal decentralisation and the size of local government. Fiscal decentralisation reduces routine social conflicts during decentralisation but it is only with applied to richer districts.

Despite the fruitful results, prior studies have several limitations. First, most of them link the significant outbreak of violence during the political transition with the decentralisation reform directly, implying that decentralisation was a cause of the violence (see Klinken, 2007; Welsh, 2008). Second, from a temporal variation perspective at the national level, these studies ignore the spatial variations in communal conflicts following local political transition and decentralisation reform. Ignoring spatial dimension of communal conflict may result in bias estimate in which the results unable to control unobserved factors across districts that may relate to widespread communal conflicts incidence (Morenoff \& Sampson, 1997). Third, some of prior studies used limited geographical coverages. For example, Murshed et al. (2009) study only covered districts within 
Java Island and therefore the findings can only be generalized within social conflicts across districts in this Island.

This paper aims to address prior studies limitations by examining the spatial aspects of sub-national communal conflict in Indonesia. The study assesses political, ethno-cultural, institution, and economic pathways of communal conflict in Indonesia and examine how communal conflict is spatially correlated across districts. Four research questions are addressed in this paper: How is spatial distribution of communal conflict incidence across districts in Indonesia? In what ways communal conflicts occur across districts? What are the risk factors associated with communal conflicts incidence across districts? Does communal conflicts across districts contagious or latent issues? In order to answer these questions the study employs the Village Potential Census Data or Podes data 2008. The data consists of more than 7,200 villages across all 465 districts in the country. Spatial linear regression analysis is used to test whether communal conflict is contagious or latent issues. Because this study examines communal conflicts and its determinants, the next section discusses a literature review on communal conflicts and its determinants. Then, it discusses the spatial aspects of community conflicts.

\section{Understanding Communal Conflicts Determinants}

Communal conflict in this paper is defined as violent conflict between non-state groups that are organised along a shared communal identity (Galtung, 1965). The groups involved are non-state groups, meaning that neither actor controls the state and armed forces (although state actors may be involved as an important supporting actor in a communal conflict). These groups are often organised along a shared communal identity, meaning that they are not formally organized rebel groups or militias but that the confrontation takes place along the line of group identities. Following Gurr (2000), communal identity is conceptualised as subjective group identification based on a common history, a common culture or common core values. In this definition, communal identity also refers to ethnic or religious identity.

Studies to understand determinants of communal conflicts have well documented (Sambanis, 2004; Coppel, 2006; Stewart, 2008; Baron et al., 2009). In general, there are four theoretical approaches which explain the prevalence of communal conflicts and the likelihood of it escalating into violence. Table 1 summarizes these approaches.

\section{Table 1.}

\section{Four Approaches for Understanding Communal Conflicts Determinants}

\begin{tabular}{cl}
\hline Approaches & \multicolumn{1}{c}{ Basic Assumptions } \\
\hline Ethno-cultural & $\begin{array}{l}\text { Communal conflicts are } \\
\text { rooted in the dynamics of } \\
\text { difference within inter-group } \\
\text { relations where groups saw } \\
\text { themselves as different due } \\
\text { to ethnic and culture. } \\
\text { Politics } \\
\text { Communal conflicts occur } \\
\text { due to elite political interest } \\
\text { and unequal state policy } \\
\text { favouring one ethnic } \\
\text { community. } \\
\text { Communal conflicts occurs } \\
\text { due to the weakness of } \\
\text { institution such as weak } \\
\text { law enforcement and norms } \\
\text { governing life } \\
\text { Communal conflicts are } \\
\text { rooted within economic } \\
\text { factors such as economic } \\
\text { rivalries and supply of public } \\
\text { goods, poverty, and economic } \\
\text { inequality. }\end{array}$ \\
\hline
\end{tabular}

Sources: Sambanis, 2004; Coppel, 2006; Stewart, 2008; Baron et al., 2009.

First, ethno-cultural approach which argues that communal conflicts are rooted in 
the dynamics of difference within inter-group relations where groups saw themselves as different due to ethnic and cultural background (Hegree et. al, 2001). Such differences are not static and given. In Indonesia for example Baron et al. (2009) found such identities morphed based on a range of factors including population movements, the political motivations of religious and ethnic leaders, and the extent to which religious and ethnic common institutions (for example places of worship) existed.

Second, institutional approach which argue that communal conflicts occurs due to the weakness of institution such as weak law enforcement and norms governing life within community. In the absence of a formal rule of law, these customary rules sometimes clashed with each other and with formal state legislation (Baron et al., 2009). In Indonesia, for example, communal conflicts over land often occur due to different kinship groups had different rules and understandings of how land should be allocated. This is followed by lack of capacity of local leaders and state institution particularly security sector to make and to enforce decisions. Hence, the inability of the state to control conflict becomes the pathway of how small protests and demonstrations may end up in large community conflict.

Third, political approach which argue that communal conflicts occurs due to unequal state policy favoring one ethnic community (Horowitz, 1985). In Indonesia, for example, Java has dominated government structure for long time and therefore state policies in favor Java ethnic rather than others. In other case, the competition over political representations also gives a reason for conflict, in which some of the conflicts occurs during election campaigns. Competition over political representation often uses both ethnic division to mobilise support and intra-elite competition at local level to manipulate long term primordialist social patterns (Coppel, 2006).

Fourth, economic approach which argue communal conflicts are rooted within economic factors such as economic rivalries and supply of public goods, poverty, and economic inequality (Mancini, 2005). The classical literature of communal conflict states that countries or regions with poorer and more unequal distribution of wealth are held to be more vulnerable to various forms of political violence (Stewart, 2008; Gleditsch et al., 2009). The existing literature provides a strong theoretical foundation of how poverty and economic inequality lead to polarization of group belonging which facilitate group mobilization to violence collective action. For example, Collier \& Hoeffler (2004) explains that groups that are disadvantaged in the distribution of resources share both a common grievance and a common identity, which facilitate recruitment for radical action to assert and to protect group interests.

\section{Spatial Aspect of Communal Conflicts}

Spatiality has gained increasing attention within communal conflict literature, especially from the perspective of space not merely as a static product but rather as an active agent that informs and affects inter-groups relations. The importance of spatiality in communal conflict studies address limitation of closed polity approach which assumes that community conflict is a function of the specific characteristics prevailing in individual communities and disregards the potential influence or regional factors (Sambanis, 2005). In contrast, spatial approach of community conflict assumes that communal conflicts tend to cluster spatially in certain geographic areas. A number of studies have shown that countries in proximity to states involved in violent conflict (Ward \& Gleditsch, 1998; Weidman \& Ward, 2010).

Previous studies identified two mechanisms by which spatial may affect communal conflicts Ward \& Gleditsch, 1998; Buhaug \& Gleditsch, 2008; Weidman \& Ward, 2010). First, contagious effects assume that communal conflicts spread through space much 
like a disease, which potentially devastating consequences for human development. A large empirical literature documents the fact that communal conflicts cluster in space and time, so that areas close to an already existing conflict are more likely to become involved in conflicts themselves (Buhaug \& Gleditsch, 2008). This literature had led some to conclude that conflicts have a propensity for contagion, in the sense that a communal conflict in one region may bring about the onset of communal conflict in a nearby region within a short time period.

Second, latent effects assume that communal conflict clusters appear due to regional similarity. Hence, the geographic clustering of community conflicts may arise due to a corresponding clustering of domestic factors believed to promote conflict. In this case, any apparent distributional pattern of conflict disappears due to a systematic fashion of domestic factors. Hegre et al. (2001) for example found evidence of contagion of conflict from neighboring states, and conclude that the apparent clustering of civil war is fully explained by the clustering of domestic factors such as the absence of democratic institutions. Moreover, many economic shocks known to cause conflicts, like droughts and changes in commodity prices which are also associated with space. In this case, what looks like contagion might simple direct results of such economic shocks that affect a wider geographical area and sparked conflicts over a short period of time (Buhaug \& Gleditsch, 2008).

\section{Research Methods}

\section{a. Data and Variables}

The Village Potential Cencus (Podes) 2008 dataset were used to examine by which spatial determinants lead to communal conflict across districts in Indonesia. The Podes is a long standing tradition of collecting data at the lowest administrative tier of local government.
Podes consist of more than 7,200 villages (desa) and urban neighborhoods (kelurahan) across all 465 districts in Indonesia. The census has been conducted every two years by the Indonesia Central Bureau of Statistic (Biro Pusat Statistik) since 1983. Detailed information is gathered on a range of characteristics- ranging from public infrastructures to village finance. Information is gathered from kepala desa (rural village heads) and lurah (urban neighborhood heads). Since 2003, Podes included questions to measure communal conflicts within village. In this study, we used Podes 2008 which also have information about communal conflicts and the impacts of the conflicts (fatalities, injuries, and material damage). Podes 2008 also include some information about malnutrition case, religion, ethnicity, migrant people, land converted to industry, mining areas, village head education, and distance from village to district government administration.

This study links the communal conflict data from Podes 2008 with official statistics. First, it linked the Podes data with Gross Domestic Data (GDP) 2008 from the Indonesia Central Bureau of Statistics. Second, poverty, Gini Index and population data were retrieved from the Indonesia Central Bureau of Statistics. Poverty was calculated from household expenditure questionnaires of Social Economic Survey (Susenas) 2008. Third, the study also linked the Podes 2008 data with age of local election data from the Ministry of Home Affairs to examine whether age of local democracy as measured by age of local election relates with communal conflicts. Fourth, we retrieved information about existing political dynasty from the Ministry of Home Affairs. Fifth, district balancing fund data or dana alokasi umum was linked to test whether fiscal decentralisation affects communal conflicts across districts. The district balancing fund data were retrieved from the Ministry of Finance. Sixth, the geographical areas and latitude/longitude data were used to examine whether districts in the borders areas 
have higher risk to communal conflicts than other districts.

Following the theoretical approaches which explain the prevalence of communal conflicts and the likelihood of it escalating into violence, we include four determinants which capture the approaches. First, Gini Index, poverty and malnutrition cases within a district are used to examine economic pathways of the incidence of communal conflict. Second, to examine ethno-cultural pathways of communal conflicts we include multiple religions and ethnic group indicators. Third, age of direct of local democracy, village head education and district balancing fund are used to test institutional pathways of communal conflicts. Fourth, existing political dynasty is included to test political pathways of communal conflicts. Local democracy in Indonesia has been characterised by raja-raja kecil (little king) which results in political dynasty within local government. Table 2 below shows determinants

Table 2.

Determinants, Definition and Data Sources

\begin{tabular}{|c|c|c|}
\hline Determinants & Definition & Sources \\
\hline Communal conflict & $\begin{array}{l}\text { Total number of communal conflict within a } \\
\text { district in } 2008\end{array}$ & BPS Podes 2008 \\
\hline Gini Index & District Gini Index in 2008 & BPS 2008 \\
\hline Poverty & Mean of poor people within district in 2008 & BPS Susenas 2008 \\
\hline $\begin{array}{l}\text { Log district gross } \\
\text { domestic product }\end{array}$ & $\begin{array}{l}\text { Logarithmic value of district gross domestic } \\
\text { product in } 2008\end{array}$ & BPS 2008 \\
\hline $\begin{array}{l}\text { Proportion of villages } \\
\text { with malnutrition case }\end{array}$ & $\begin{array}{l}\text { Percentage of villages within district with } \\
\text { malnutrition case in } 2008\end{array}$ & BPS Podes 2008 \\
\hline Multiple religion & $\begin{array}{l}\text { Percentage of villages within a district with } \\
\text { more than one religion in } 2008\end{array}$ & BPS Podes 2008 \\
\hline Multiple ethnic groups & $\begin{array}{l}\text { Percentage of villages within a district with } \\
\text { more than one ethnicity in } 2008\end{array}$ & BPS Podes 2008 \\
\hline Age of direct democracy & $\begin{array}{l}\text { Age of direct local government election (pilkadal) } \\
\text { in } 2008\end{array}$ & MoH 2008 \\
\hline Political dynasty & District with political dynasty in 2008 & MoH 2014 \\
\hline $\begin{array}{l}\text { Log district general } \\
\text { balancing fund }\end{array}$ & $\begin{array}{l}\text { Logarithmic of district general balancing fund } \\
\text { (dana alokasi umum) in } 2008\end{array}$ & SIKD 2007 \\
\hline Close to state borders & $\begin{array}{l}\text { Dummy indicators indicating districts located in } \\
\text { or around state border. }\end{array}$ & MoH 2008 \\
\hline Share migrants & $\begin{array}{l}\text { Percentage of migrant people on total } \\
\text { population in } 2008\end{array}$ & BPS-Podes 2008 \\
\hline Share of urban area & $\begin{array}{l}\text { Percentage of urban area within a district in } \\
2008\end{array}$ & BPS-Podes 2008 \\
\hline $\begin{array}{l}\text { Land converted to } \\
\text { industry }\end{array}$ & $\begin{array}{l}\text { Percentage of land converted by industries } \\
\text { within a district in } 2008\end{array}$ & BPS-Podes 2008 \\
\hline Mining area & District has a mining area & BPS-Podes 2008 \\
\hline $\begin{array}{l}\text { Distance to government } \\
\text { administration }\end{array}$ & $\begin{array}{l}\text { Distance in kilometres between villages to } \\
\text { district government administration }\end{array}$ & BPS-Podes 2008 \\
\hline Log population & $\begin{array}{l}\text { Logarithmic total number of district population } \\
\text { in } 2008\end{array}$ & BPS 2008 \\
\hline Eastern Indonesia & Eastern part of Indonesia & BPS-Podes 2008 \\
\hline District proliferation & $\begin{array}{l}\text { A dummy variable indicating a proliferated } \\
\text { district (pemekaran) }\end{array}$ & MoH 2008 \\
\hline
\end{tabular}


of communal conflicts that are included in the model, definitions and sources of data.

Geographical determinants such as district at and around state border, share of urban area, and land converted to industry are included to control whether geographic proximity and urban development relate with communal conflicts. Demographic determinants such as share of migrants and total population are included to control whether migration and population affect communal conflict. Likewise, eastern Indonesia and district proliferation are included since decentralisation encourages local elite to create new district governments.

\section{b. Statistical Analysis}

We applied several statistical analyses to describe spatial distribution of communal conflicts and to test whether the incidence of communal conflict is contagious or latent issues. First, spatial descriptive analysis was used to describe spatial distribution of communal conflicts across districts in Indonesia. Communal conflict maps were created using spmap program in STATA 13.0. Second, in order to test whether communal conflicts across districts are contagious or latent issues, we used spatial linear regression analysis. We compare estimations results of Ordinary Least Square (OLS), spatial lag and spatial error models in the analysis to test the contagious or latent issues of communal conflict incidents (Bivand et al., 2008).

\section{Results}

This section presents the results. We begin by presenting spatial distribution of communal conflicts and then present the results of spatial regression.

\section{Spatial Distribution of Communal Conflicts}

Figure 1 describes spatial distribution of communal conflict in Indonesia. The highest incidence shows at district across Papua province particularly districts in the border areas such as Jayapura, Mappi, Mamberamo Raya and Supiori. Most of these districts are new created districts which are established following decentralisation. High number of communal conflict also occurs across districts at North Sumatra province such as Langkat, Deli Serdang, and Karo as well as Aceh province such as Aceh Tengah, Aceh Besar, and Aceh Tenggara. It also shows a dense communal conflict in Jakarta, capital city of Indonesia and Tangerang district in Banten province. Tangerang is also recognised as a new district created following decentralisation.

Figure 2 describes number of population death caused by communal conflict across

Figure 1.

\section{Spatial Distribution of Communal Conflict in Indonesia 2008}

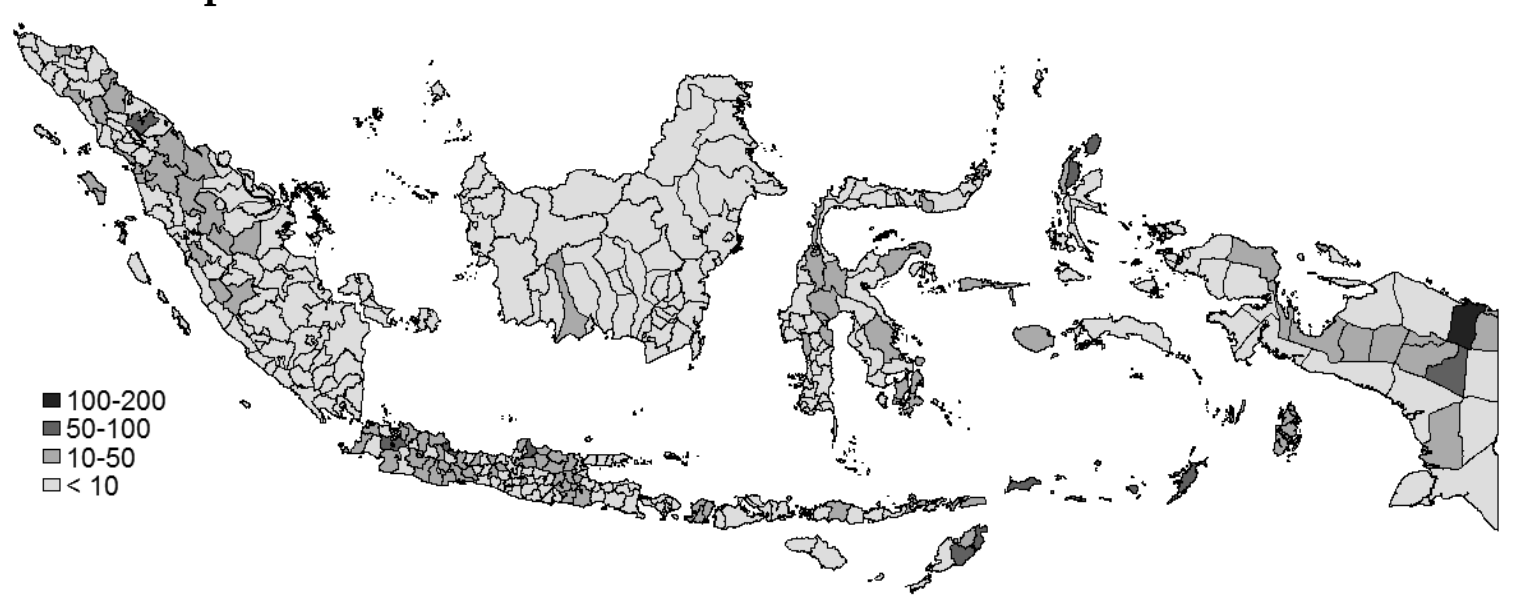

Source: Podes 2008 communal conflict data calculated by author 
districts in Indonesia 2008. The high number of death is showed across districts at Papua, particularly districts in the border areas such as Jayapura, Mappi, Mamberamo Raya, Yahukimo, and Supiori. A high number of deaths are also showed at some districts at Central Sulawesi and North Sumatra.

Not only death, communal conflict also results in material lost. Figure 3 shows geographical distribution of material lost due to communal conflict across districts in Indonesia. The highest number of material lost occurs at districts across East Papua, some districts at North Sumatra, Aceh, and West Java province. However, we do not find a substantial material loss of communal conflict at Kalimantan province and some district at Central Java, Yogyakarta and southern part of East Java province.

\section{Determinants of Communal Conflicts}

Table 3 shows regression results of political, institutional, economic and ethnocultural determinants of communal conflicts in Indonesia. The coefficient of OLS, spatial error, and spatial lag estimation show consistent

Figure 2.

Spatial Distribution of Total Death Caused by Communal Conflict in Indonesia 2008

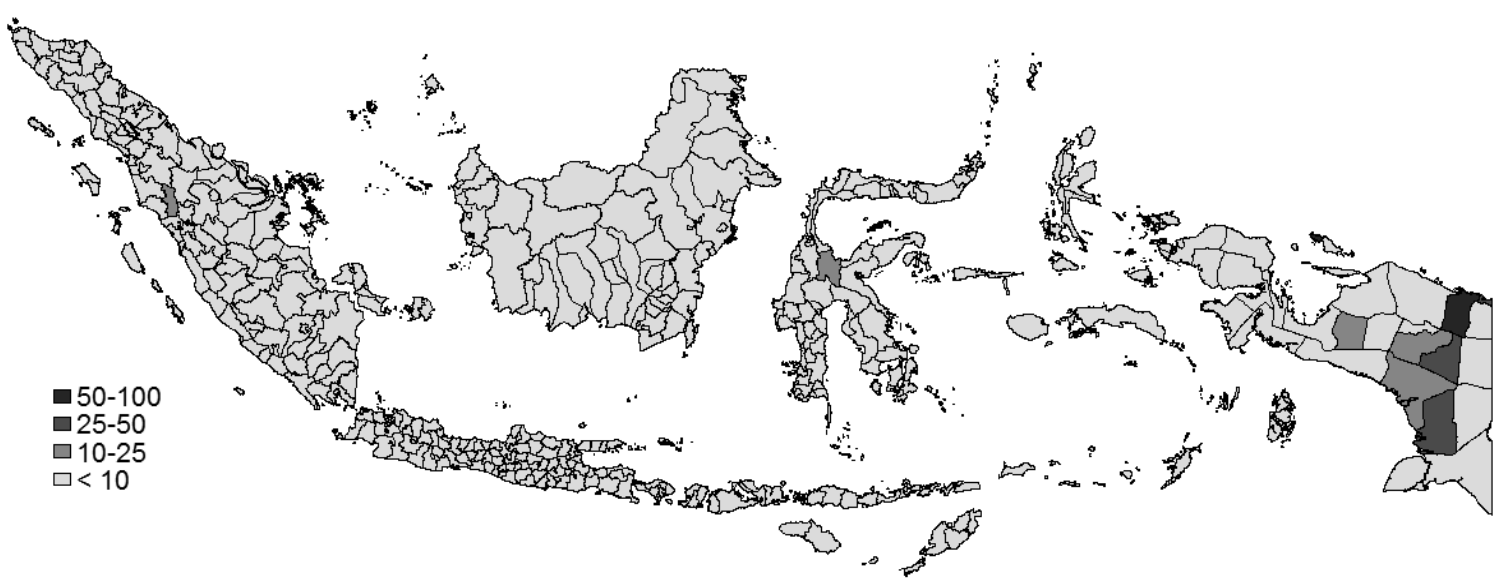

Source: Podes 2008 communal conflict data calculated by author

Figure 3.

\section{Spatial Distribution of Material Lost (In Million Rupiah) Due to Communal Conflict in Indonesia 2008}

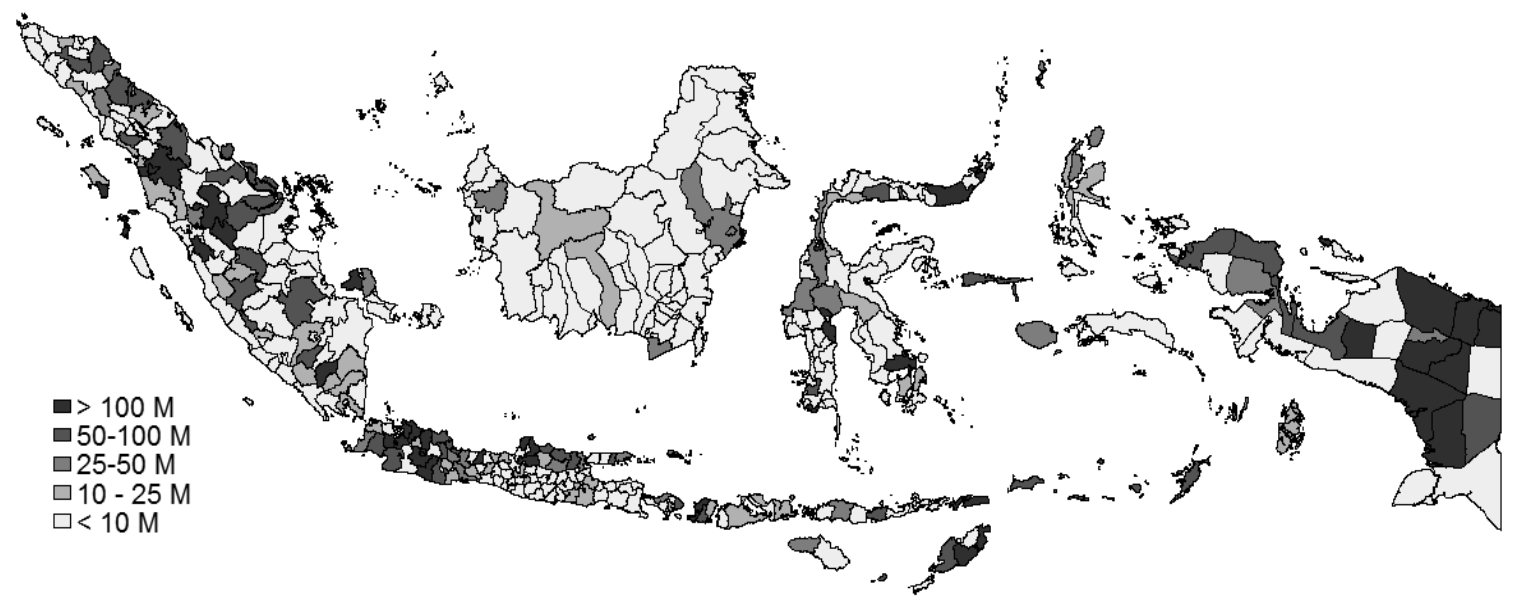

Source: Podes 2008 communal conflict data calculated by author 
Table 3.

Regression Results of Communal Conflict in Indonesia 2008

\begin{tabular}{lrrrrrr}
\hline & \multicolumn{2}{c}{ OLS } & \multicolumn{2}{c}{ Spatial Error } & \multicolumn{2}{c}{ Spatial Lag } \\
\cline { 2 - 6 } & \multicolumn{1}{c}{ Coef. } & \multicolumn{1}{c}{ se } & \multicolumn{1}{c}{ Coef. } & \multicolumn{1}{c}{ se } & \multicolumn{1}{c}{ Coef. } & \multicolumn{1}{c}{ se } \\
\hline Gini index & $40.813^{* * *}$ & 13.291 & $38.183^{* * *}$ & 12.481 & $42.764^{* * *}$ & 13.157 \\
Poverty & $12.495^{* * *}$ & 3.646 & $12.022^{* * *}$ & 3.634 & $12.201^{* * *}$ & 3.596 \\
Log district gross domestic & $1.727^{* * *}$ & 0.439 & $1.623^{* * *}$ & 0.448 & $1.752^{* * *}$ & 0.432 \\
product & & & & & & \\
Proportion of villages with & $0.700^{* * *}$ & 0.103 & $0.699^{* * *}$ & 0.102 & $0.695^{* * *}$ & 0.102 \\
malnutrition case & & & & & & \\
Multiple religion & -1.715 & 1.787 & -1.832 & 1.767 & -1.949 & 1.767 \\
Multiple ethnic groups & -6.652 & 2.671 & -6.562 & 2.641 & -6.474 & 2.632 \\
Political dynasty & $2.450^{* * *}$ & 0.231 & $2.402^{* * *}$ & 0.211 & $2.285^{* * *}$ & 0.200 \\
Age of direct democracy & 5.452 & 2.472 & 0.102 & 0.356 & 0.085 & 0.356 \\
Village head education: & $-1.410^{* * *}$ & 0.111 & $-1.312^{* * *}$ & 0.100 & $-1.215^{* * *}$ & 0.090 \\
high school and above & & & & & & \\
Log district balancing fund & $0.012^{* * *}$ & 0.003 & $0.011^{* * *}$ & 0.002 & $0.015^{* * *}$ & 0.002 \\
Close to state borders & 0.248 & 0.165 & 0.217 & 0.153 & 0.269 & 0.141 \\
Share migrants & 0.068 & 0.266 & 0.052 & 0.233 & 0.061 & 0.212 \\
Share of urban area & $5.350^{* * *}$ & 1.548 & $4.250^{* * *}$ & 1.328 & $4.310^{* * *}$ & 1.310 \\
Land converted to industry & $1.546^{* * *}$ & 0.025 & $1.326^{* * *}$ & 0.021 & $1.421^{* * *}$ & 0.018 \\
Mining area & 3.014 & 2.987 & 2.015 & 2.147 & 2.112 & 2.141 \\
Distance to government & $2.146^{* * *}$ & 0.037 & $2.116^{* * *}$ & 0.034 & $2.421^{* * *}$ & 0.021 \\
administration & & & & & & \\
Log population & & & & & & \\
Eastern Indonesia & $2.328^{* * *}$ & 0.503 & $2.327^{* * *}$ & 0.504 & $2.427^{* * *}$ & 0.401 \\
District proliferation & $2.621^{* * *}$ & 0.012 & $2.531^{* * *}$ & 0.011 & $2.611^{* * *}$ & 0.010 \\
Constant & $1.321^{* * *}$ & 0.022 & $1.211^{* * *}$ & 0.011 & $1.221^{* * *}$ & 0.010 \\
R & $-46.967^{* * *}$ & 12.437 & $-42.377^{* * *}$ & 13.442 & $-49.284^{* * *}$ & 12.737 \\
Rho & $19 \%$ & & & & & \\
Lambda & & & & & 0.0272 & 0.019 \\
\hline Reported ***p<0.01 & & & $0.881^{* * *}$ & 0.006 & & \\
\hline
\end{tabular}

results. Gini Index shows positive association with number of communal conflict indicating the detrimental effect of district economic inequality on conflict. Likewise, districts with high number of poverty and malnutrition are likely risks to communal conflict. However, log district GDP has positive relationship with communal conflict indicating that communal conflicts likely occurs in rich districts rather than in poor districts. Multiple religion and ethnic groups have negative association with communal conflict. However, the results show not significance, meaning that religion and ethnic heterogeneity seem not risk factors of community conflict across districts in Indonesia.

Political dynasty increases communal conflicts. In all models, it shows a significant association between districts with political dynasty and higher number of communal conflicts. Age of direct democracy leads to communal conflict but the relationship is not significant. Street level bureaucracy capacity as measured by village head education is negatively associated with communal conflict. However, fiscal decentralisation as measured by district balancing fund increases communal conflicts. Migration and districts located close 
to state border have high risk to communal conflict. However, this association appears not significant. Urbanisation and industrialisation both increase to communal conflict. Likewise, distance to government administration, population and district proliferation triggers communal conflict. As expected, districts located at Eastern part of Indonesia have higher risk to communal conflict.

Results of spatial error model shows significant relationship of latent factors $\left(\lambda=0.881,{ }^{* * *} p<0.01\right)$. However, results of spatial lag model shows insignificant relationship $(\mathrm{p}=0.0272, p>0.1)$ meaning that communal conflict in one district do not trigger conflict in their neighbouring districts. Otherwise, the significant results of spatial error model indicate that conflict in one particular district is likely result in from latent factors within the districts.

\section{Analysis}

This paper aims to examine spatial aspects of sub-national communal conflict and its risk factors in Indonesia. The main results show that the incidence of communal conflict in Indonesia to be spatially dependent through latent factors, meaning that communal conflict clusters due to clustering of latent factors at district level. In contrast with many qualitative findings, we do not find empirical evidence of contagious effect of communal conflict in the country (Klinken, 2007; Urwasi, 2015).

This study shows three main pathways in which communal conflicts escalate across districts. First, communal conflict between districts occurs due to endemic problems of poverty and economic inequality across districts. The empirical evidence shows that communal conflict occurs within poorer districts and districts with higher Gini Index. These results confirm classical literature of communal conflicts which provides a strong foundation of economic pathway of community conflict escalation. Stewart (2008) for instance highlight that regions with poorer and more unequal distribution of wealth are held to be more vulnerable to communal conflicts.

Second, communal conflict between districts escalates due to weaknesses of district democratic institutions and lack capacity of street level bureaucracy. As we found that risks of communal conflict appear within districts which have less capacity of village head and immature local democracy. These results confirm the work of institutional pathways in understanding communal conflict in Indonesia. Baron et al. (2009), Tajima et al. (2004) and Risa (2016), for example, found that clashed within communities often occurs due to the absence of a formal rule of law and lack of capacity of local leaders and state institution to enforce decision.

Third, communal conflict between districts in Indonesia also occurs due to political reason. The political competition during direct local election gives a reason for communal conflicts. In many cases, political competition over political representation uses ethnic division to mobilise support and intra-elite competition at district to manipulate long terms elite capture (Klinken, 2007). The rise of raja-raja kecil (little king) and dinasti politik (political dynasty) in local level following political decentralisation support this evidence. As also shows in this study that district with exist political dynasty have higher risks to community conflicts.

Another important findings show that rather than religious and ethnic heterogeneity, communal conflict across districts is positively associated with poverty, economic inequality and weak capacity of districts to manage fiscal resources. In all models, we found no significant association between religious and ethnic heterogeneity and the incidence of communal conflict. In contrast, a strong association is showed on the relation between economic, political and institutional factors of communal conflict. The significant association of these factors contrast with prior studies that strongly 
argue that religion and ethnic heterogeneity are the main determinants of communal conflict in the country (see for example, Klinken, 2007). Instead of religion and ethnic heterogeneity, this study shows that lack capacity of street level bureaucrats, immature local democracy, political dynasty, poverty and economic inequality are roots issue of communal conflict across districts in the country.

This study also found that decentralisation increases the incidence of communal conflict through lack capacity of district government in managing fiscal resources. Decentralisation has transferred abundant fiscal resources to from central government to district government. With poor capacity of district government in managing fiscal resources, in many cases the resources do not give benefits to local people and therefore triggering communal conflict. Klinken (2007) for example noted that communal conflict incidence often occurs at eastern part of Indonesia which most of them have lack capacity to manage resource. As also seen from this study, communal conflict incidents are strongly related with new districts government which most of them still have lack capacity to manage fiscal resources.

There are two limitations of these studies. First, this study is based on cross-sectional data so that it only provides one shot capture of communal conflict in Indonesia. Therefore, the future studies may useful to examine risk factors of communal conflict in the country using longer time of data. Second, the statistical analysis used in this study is unable to account the structure of Podes data which is based on village rather than on district. Future studies therefore are useful using multilevel spatial modelling to account for heterogeneity across villages within district (see for example, Morenoff \& Simpson, 1997).

Despite these limitations, this study has several important implications on the communal conflict literature in developing countries particularly Indonesia as well as policy to solve community conflict. First, the significant findings of spatial error model imply that the root issues of communal conflict in decentralised Indonesia are latent issues within districts particularly increasing poverty, economic inequality, paternalism and primordialism following political decentralisation in the country. From policy perspective, therefore, the politicians and government should notice that sooner or later the widespread of issues such as paternalism and primordialism in the country as manifested by increasing politik dinasti (political dynasty) will lead to communal conflict. Second, the significant finding of political, institutional and economic risk factors confirms prior studies across developing countries that the source of widespread of communal conflict in developing countries is acute problems of elite capture, weak institution, and poverty (see for example Murshed 2009; World Bank 2011; UNDP, 2011). These findings highlight the importance of strengthening local government capacity, local democratic institution and poverty reduction to combat communal conflicts. For Indonesia, improving local government capacity especially in managing fiscal resources to reduce poverty and to increase inclusive growth that benefit for both rich and poor people across the archipelago may be a strategic pathway.

\section{Conclusion}

In decentralised Indonesia, communal conflict to be spatially dependent through latent factors, meaning that communal conflict clusters because of clustering of latent factors within district. Rather than religious and ethnic heterogeneity, communal conflict is positively associated with poverty, economic inequality, elite capture, and weak capacity of districts to manage fiscal resources. These findings highlight the importance of strengthening local government capacity, local democratic institution and poverty reduction to combat communal conflicts across archipelago. 


\section{References}

Bivand, RS, Pebesma, EJ, \& Gomez-Rubio, V. (2008). Applied Spatial Data Analysis With R. New York: Springer.

Barron, P, Kaiser, K \& Pradhan, M. (2009). Understanding Variations in Local Conflict: Evidence and Implications from Indonesia. World Development, 37(3): 698-713.

BPS. (2011). Indonesia dalam Angka 2010. Jakarta: Indonesia.

BPS. (2015). Statistik Indonesia 2014. Jakarta: Indonesia.

Buhaug, H. \& Gleditsch, KS. (2008). Contagion or Confusion? Why Conficts Cluster in Space. International Studies Quarterly, 52 (2):215-233.

Collier, P. \& Hoeffler, A. (2004). Greed and Grievance in Civil War. Oxford Economic Papers, 56 (4): 563-95.

Coppell, CA. (2006). Violence: Analysis, Representation and Resolution. Violent Conflicts in Indonesia: Analysis, Representation, Resolution. London and New York: Routledge

Galtung, J. (1965). Institutionalized Conflict Resolution: A Theoretical Paradigm. Journal of Peace Research, 39 (5):615-37.

Gleditsch, NP, Hegre, H \& Strand, H. (2009). Democracy and Civil War. Handbook of War Studies III, ed. Midlarsky, M \& Arbor A. MI: University of Michigan Press.

Gurr, TR. (2000). Peoples Versus States: Minorities at Risk in The New Century. Washington D.C: United States Institute of Peace

Hegre, H., Ellingsen, T., Gates, S. \& Gleditsch, N. (2001). Towards a Democratic Civil Peace? Democracy, Civil Change, and Civil War 1816-1992. American Political Science Review, 95(1): 17-33.

Klinken, GV. (2007). Communal Conflict and Decentralisation in Indonesia. The Australian Centre for Peace and Conflict Studies Occasional Paper No. 7.
Mancini, L. (2005). Horizontal Inequality and Communal Violence: Evidence from Indonesian Districts. CRISE Working Paper 22. Oxford: QEH, University of Oxford

Morenoff, JD., \& Sampson, RJ. (1997). Violent Crime and The Spatial Dynamics of Neighborhood Transition: Chicago 19701990. Social Forces 76(1):31-64.

Murshed, SM, Tadjoeddin, MZ, \& Chowdurry, A. (2009). Is Fiscal Decentralization Conflict Abating? Routine Violence and District Level Government in Java, Indonesia. Oxford Development Studies, 37(4).

Toha, RJ. (2016). Political Competition and Ethnic Riots in Democratic Transition: A Lesson from Indonesia. British Journal of Political Science, 2(1):1 - 21.

Sambanis, N. (2004). What is a Civil War? Conceptual and Empirical Complexities of an Operational Definition. Journal of Conflict Resolution, 48(6): 814-858.

Stewart, F. (2008). Horizontal Inequalities and Conflict: Understanding Group Violence in Multi-ethnic Societies. Hampshire and New York: Palgrave Macmillan.

Tajima, Y. (2004). Mobilizing for Violence: The Escalation and Limitation of Identity Conflicts: The Case of Lampung, Indonesia. Indonesian Social Development Paper No. 3. Jakarta: World Bank.

UNDP. (2011). Conflict in Developing Countries. Paris: UNDP.

Urwasi, W. (2014). Spatial Segregation and EthnoReligious Violence: A Lesson from Ambon, Indonesia. EDGS Working Paper Number 32.

Ward, MD. \& Gleditsch, KS. (1998). Democratizing for Peace. American Political Science Review, 92(1): 51-61.

Weidmann, NB. \& Ward, MD. (2010). Predicting Conflict in Space and Time. Journal of Conflict Resolution, 54:883-901.

World Bank. (2011). Conflict, Security, and Development. Washington DC: World Bank. 